\title{
Soil gas geochemical behaviour across buried and exposed faults dur- ing the 24 August 2016 central Italy earthquake
}

\author{
GIANCARLO CIOTOLI ${ }^{1,2 *}$, ALESSANDRA SCIARRA ${ }^{2,1,5}$, LIVIO \\ RUGGIERO3, ALDO ANNUNZIATELlis, ${ }^{4}$, , SABINA BIGI ${ }^{3}$ \\ ${ }^{1}$ Consiglio Nazionale delle Ricerche - Istituto di Geologia \\ Ambientale e Geoingegneria, Rome, Italy \\ 2Istituto Nazionale di Geofisica e Vulcanologia, Rome, Italy \\ 3Università degli Studi di Roma La Sapienza, Rome, Italy \\ ${ }^{4}$ Istituto Superiore per la Protezione e la Ricerca Ambientale, \\ Rome, Italy \\ ${ }^{5}$ Università degli Studi di Ferrara, Ferrara, Italy
}

*giancarlo.ciotoli@igag.cnr.it

\begin{abstract}
Following the earthquake $\left(M_{L}=6.0\right)$ of 24 August 2016 that affected large part of the central Apennine between the municipalities of Norcia (PG) and Amatrice (RI) (Central Italy), two soil gas profiles (i.e., ${ }^{222 R n},{ }^{220} \mathrm{Rn}, \mathrm{CO}_{2}$ and $\mathrm{CO}_{2}$ flux) were carried out across buried and exposed coseismic fault rupture of the Mt. Vettore fault during the seismic sequence. The objective of the survey was to explore the mechanisms of migration and the spatial behaviour of different gas species near still-degassing active fault. Results provide higher gas and $\mathrm{CO}_{2}$ flux values (about twice for ${ }^{222} \mathrm{Rn}$ and $\mathrm{CO}_{2}$ flux) in correspondence of the buried sector of the fault than those measured across the exposed coseismic rupture. Anomalous peaks due to advective migration are clearly visible on both side of the buried fault (profile 1), whereas the lower soil gas concentrations measured across the exposed coseimic rupture (profile 2) are mainly caused by shallow and still acting diffusive degassing associated to faulting during the seismic sequence. These results confirm the usefulness of the soil gas survey to spatially recognise the shallow geometry of hidden faults, and to discriminate the geochemical migration mechanisms occurring at buried and exposed faults related to seismic activity.
\end{abstract}

\section{INTRODUCTION}

$S^{0}$ il gas survey has been widely used to trace buried faults and to study the behaviour in the shallow environment of endog- enous gases with different origins (i.e., trace gases, i.e., radon and helium, and carrier gases i.e., carbon dioxide, nitrogen, methane, etc.) and [e.g., King, 1985; Baubron et al., 2002; Ciotoli et al., 2007; Fu et al., 2008; Walia et al., 
2009; Ciotoli et al., 2014; Bigi et al., 2014; Sciarra et al., 2014]. Furthermore, over the past several years' soil gases has captured considerable attention as earthquake precursors [Wakita et al., 1980; Reddy et al., 2004; Walia et al., 2009; Perez et al., 2007; Ghosh et al., 2009; Hashemi et al., 2013; Petraki et al., 2015], in fact that the stress/strain changes related to seismic activity may force crustal fluid to migrate up, especially along active faults, thereby altering the geochemical characteristics of the fault zone at surface [Rice, 1992; Sibson, 2000; Collettini et al., 2008]. The migration of these gases by diffusion and/or advection along buried active faults can generate shallow anomalies with concentrations significantly higher than background levels; these anomalies can provide reliable information about the location and the geometry of the shallow fracturing zone, as well as about the permeability within the fault zone [King et al., 1996; Baubron et al., 2002; Ciotoli et al., 2007; Annunziatellis et al., 2008; Bigi et al., 2014; Sciarra et al., 2014].

Among the soil gases, ${ }^{222} \mathrm{Rn}$, a radioactive inert gas with a half-life of 3.82 days, is considered a convenient fault tracer in geosciences, because of its ability to migrate to comparatively long distances from host rocks, as well as the efficiency of detecting it at very low levels. While other gases have also been considered as tracer of hidden faults, however, bulk of reports in the scientific literature are focused on radon. Local increases in radon emanation along faults could be caused by a number of processes, including precipitation of parent nuclides caused by local radium content in the soil [Tanner, 1964; Zunic et al., 2007], increase of the exposed area of faulted material by grainsize reduction [Holub and Brady, 1981; Koike et al., 2009; Mollo et al., 2011], and carrier gas flow around and within fault zones [e.g., King et al., 1996; Annunziatellis et al., 2008]. Given the acceptance that the concentrations of radon gas are the result of advective gas flow associated with elevated permeability in fault zones, soil gas surveys are widely regarded to be an effective tool to map buried or blind faults not detected during mapping of the surface geology [King et al., 1996; Burton et al., 2004; Ciotoli et al., 2007, 2015, 2016].

Soil gas migration does not necessarily occur in the same way through all faults, and the mechanism is still disputed. Two possible scenarios can be considered: in correspondence of hidden faults, with low permeability core bounded by damage zones, high soil gas concentrations should occur laterally above the fracture zones. In contrast, in correspondence of exposed and fresh faulted zones the open fracture network provides interconnected gas migration pathways, resulting in low gas concentrations and higher gas flux rates [Annunziatellis et al., 2008].

This paper is aimed to study the processes that produce gas anomalies of radon isotopes, ${ }^{220} \mathrm{Rn}$ and ${ }^{222} \mathrm{Rn}$, and $\mathrm{a} \mathrm{CO}_{2}$ as carrier gas, in correspondence of the Vettore-Gorzano active fault system (about $20 \mathrm{~km}$ long, with direction NNW-SSE, $W$ dipping) that generated the strong earthquake $\left(\mathrm{M}_{\mathrm{L}}=6.0\right)$, and the seismic sequence of the central Apennine on 24 August 2016 between the municipalities of Norcia (Perugia) and Amatrice (Rieti) (Fig. 1a). The movement of this fault caused an extension of the Apennine range of about 3-4 $\mathrm{cm}$ between the Tyrrhenian and Adriatic coast [AMA_LOC Working Group 2016]. Starting from the nucleation point (about $8 \mathrm{~km}$ deep in the proximity of the Accumoli village), the rupture of the fault propagated both towards NO and SE. Accelerometer and SAR data indicated that the fault is not homogeneously displaced along its length, but is characterized by two main areas 
of displacement (maximum about $1 \mathrm{~m}$ ) on the fault plane.

Concentration of ${ }^{222} \mathrm{Rn},{ }^{220} \mathrm{Rn}$ and $\mathrm{CO}_{2}$ in soil gas and the $\mathrm{CO}_{2}$ flux was measured along two profiles crossing buried and exposed sectors of the fault coseismic rupture that extends for about $5.2 \mathrm{~km}$ along the SW flank of the Mt. Vettore (Fig. 1b). In order to explore the possible mechanisms of soil gas transport near active fault, we infer that gas anomalies are originated by both (1) advective flow along the fault zone, and (2) increased diffusive migration in the soil due to surface processes associated with faulting.

\section{METHODS}

The Mt. Vettore-Mt. Bove fault system, together with the Mt. Castello-Mt. Cardosa system, and the Norcia-Mt. Fema system [Calamita and Pizzi, 1993; Calamita et al., 1993], is a part of the Sibillini regional thrust that bounds the Apennine mountain front, separating it from the Marche-Abruzzi foothills. This thrust was active all along the Messinian and controlled the position of the southern basin margin [Milli et al., 2007; Bigi et al., 2009], superimposing the pelagic Meso-Cenozoic carbonates successions onto the Laga Messinian turbidite deposits [Centamore et al., 1992; Bigi et al., 2011]. The post-orogenic structures in the study area consist on Pliocene-Quaternary $\mathrm{N} 150^{\circ}$ highangle normal, oblique and, subordinately, strike-slip faults [Tavani et al., 2012]. These fault systems are formed by fault segments (generally, WSW-dipping) with an en-échelon geometry or connected to each other by transfer faults. The main slip surfaces of the fault crop out along the western slopes of the Mt. Vettore, forming prominent fault scarps [Pierantoni et al., 2013].
The Mt. Vettore-Mt-Porche carbonatic structure belongs to the basal hydrogeological complex of the Mts. Sibillini carbonatic hydrostructure constituted by Calcare Massiccio, Corniola formations and separated by the silicic-calcareous complex from the upper aquifer of the Maiolica system. The hydrogeological flow direction of the basal complex is affected by the main tectonic elements of the area, thus resulting in a N-S drainage along the structure [Boni \& Petitta, 2007; Nanni \& Petitta, 2012]. Few springs occur on the eastern side of the Sibillini Mts. along of the structural contact (i.e., Sibillini thrust) between the carbonate hydrostructure of the Mt. Vettore and the Laga flysch at about $900 \mathrm{~m}$ a.s.l. [Boni et al., 1987].

In this area, soil gas measurements were carried out along two parallel profiles (P1 and P2) crossing buried and exposed sectors of the Mt. Vettore fault system, respectively (Fig. 1b). The exposed fault is represented by a coseismic rupture with an offset of about $20 \mathrm{~cm}$ visible in the field at $1500 \mathrm{~m}$ a.s.l. (Fig. 1c). The rupture crosses the road SP34 and at about $1400 \mathrm{~m}$ a.s.l. is buried under the sedimentary cover of a small valley; in the valley a morphological scarp of about $4-5 \mathrm{~m}$ occurs along the fault direction (Fig. 1d).

Soil-gas and flux measurements were performed in September in a period of stable meteorological conditions (i.e., an average day temperature of $25^{\circ} \mathrm{C}$ and no precipitation). A total 50 soil gas samples, as well as $69 \mathrm{CO}_{2}$ flux measurements, were collected along two profiles according to a sampling distance ranging from 10 to $30 \mathrm{~m}$. Soil gas samples were collected using a $6.4 \mathrm{~mm}$, thick-walled, stainless-steel probe pounded in the soil at a depth of about 0.6-0.8m by using a co-axial hammer [Ciotoli et al., 2007; Beaubien et al., 2015]. Soil gas was pumped from the probe into the portable devices at the velocity of $1 \mathrm{~L} \mathrm{~m}^{-1}$. The sampling 


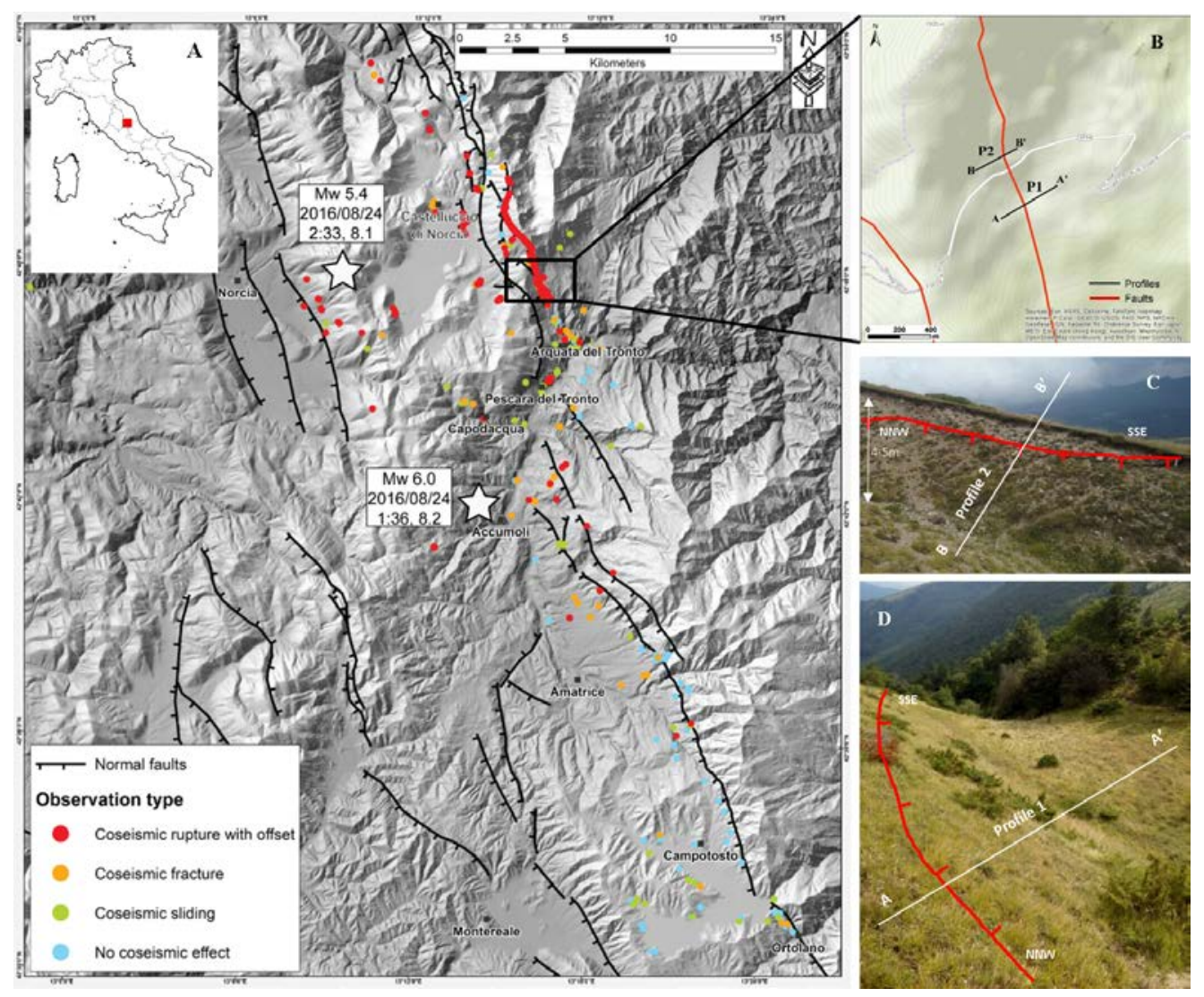

Figure 1. The figure shows: Digital Terrain Model of the area hit by the earthquake (ML=6.0) of 24 August 2016 that affected large part of the central Apennine between the municipalities of Norcia (PG) and Amatrice (RI) (Central Ita$l y)$, with different type of field recognised coseismic ruptures (A); the location of the soil gas profiles (B); photos of the investigated sites ( $C$ and $D)$.

depth ensures little influence of meteorological parameters due infiltrating atmospheric air [Hinkle, 1994]. Soil gas analysis have been conducted by using a portable gas analyser (Draeger X-am 7000, accuracy $<5 \%$ ) connected to the probe for simultaneous analyses of carbon dioxide $\left(\mathrm{CO}_{2}\right.$, range $\left.0-100 \%\right)$, oxygen $\left(\mathrm{O}_{2}\right.$, range $0-21 \%)$, methane $\left(\mathrm{CH}_{4}\right.$, range $0-100 \%$ LEL), hydrogen $\left(\mathrm{H}_{2}\right.$, range $\left.0-600 \mathrm{ppm}\right)$ and hydrogen sulphide $\left(\mathrm{H}_{2} \mathrm{~S}\right.$, range $\left.0-1000 \mathrm{ppm}\right)$. Radon and thoron were measured by using Durridge RAD7 instrument $(+/-5 \%$ absolute accuracy, and a sensivity of $0.25 \mathrm{cpm} /(\mathrm{cCi} / \mathrm{L})$,
$0.0067 \mathrm{cpm} /\left(\mathrm{Bq} / \mathrm{m}^{3}\right)$ and performing three/four measurements of radon and thoron activity each with 5-minute integration time. The measurement is repeated until the difference of the last two integrations was reduced at least below $10-5 \%$. The result was determined by taking the average of the last two integrations. $\mathrm{CO}_{2}$ flux measurements were accomplished by using the West System (West Systems TM) accumulation-chamber method equipped with beam $\mathrm{CO}_{2}$ infrared sensor (LICOR LI8200) with an accuracy of $2 \%$, repeatability \pm 5 ppmv and full scale range of 
2000 ppmv, and wireless data communication to a palm-top computer. The gas fluxes are automatically calculated through a linear regression of the gas concentration build-up in the chamber.

\section{RESULTS}

Data statistics for $\mathrm{CO}_{2}, \mathrm{O}_{2},{ }^{222} \mathrm{Rn}$ and ${ }^{220} \mathrm{Rn}$ are listed in table 1. No detectable concentrations of $\mathrm{CH}_{4}, \mathrm{H}_{2}$ and $\mathrm{H}_{2} \mathrm{~S}$ were observed. Generally, soil gas samples exhibited high concentrations compared with atmospheric air content $\left(\mathrm{CO}_{2}\right.$ : $0.036 \%,{ }^{222} \mathrm{Rn}$ and ${ }^{220} \mathrm{Rn}: 0.01 \mathrm{kBq} \mathrm{m}^{-3}$ ) [Ciotoli et al., 2007]. The calculation of the main statistical indexes indicates clear differences of the mean values for ${ }^{222} \mathrm{Rn}$ and ${ }^{220} \mathrm{Rn}$ between the two profiles: higher mean values are calculated across the buried sector of the fault (Fig. 2a, P1), whereas lower mean values occur across the coseismic rupture (Fig. 2b, P2). Comparable $\mathrm{CO}_{2}$ mean concentrations were observed along both profiles.
$\mathrm{CO}_{2}$ flux values also show a higher mean for the $\mathrm{P} 1$, approximately twice than that calculated for the P2, and a high variability being affected by the vegetation, shallow soil characteristics (i.e., porosity, fracturing, moisture content, temperature, etc.), as well as meteorological conditions (i.e., wind speed, air temperature, rainfall, etc.) [Metzger et al., 2008]. Normal Probability Plots (NPP) were used to statistically select background, anomalous values and extra outliers of the collected data [Sinclair, 1991; Ciotoli et al., 2007]; in particular values above $10 \mathrm{kBq} \mathrm{m}^{-3}$ for ${ }^{222} \mathrm{Rn}, 6 \mathrm{kBq} \mathrm{m}^{-3}$ for ${ }^{220} \mathrm{Rn}$, and $1.0 \%$ for $\mathrm{CO}_{2}$ have been considered as "anomalies". Furthermore, $\mathrm{CO}_{2}$ flux values above $20\left(\mathrm{~g} \mathrm{~m}^{-2}\right.$ day $\left.^{-1}\right)$ may be considered statistically anomalous, as background values can be approximately defined by the vegetation contribution (up to $10 \mathrm{~g} \mathrm{~m}^{-2}$ day $^{-1}$ ) from meadows and pasture typical of this mountain environments in central Italy [Bahn et al., 2008]..

Table 1. Main statistics of soil gas data collected along the two profiles. CI, Confidence Interval; GM, Geometric Mean; Min, Minimum value; Max, Maximum value; LQ, Lower Quartile; UQ, Upper Quartile; St.Dev. Standard Deviation. Gas concentrations are expressed: carbon dioxide, $\mathrm{CO}_{2}(\%, v / v)$; oxygen, $\mathrm{O}_{2}(\%, v / v)$; radon isotopes, ${ }^{222} \mathrm{Rn}$ and ${ }^{220} \mathrm{Rn}$ $\left(\mathrm{kBq} \mathrm{m} \mathrm{m}^{-3}\right)$ and flux of $\mathrm{CO}_{2}, \phi \mathrm{CO}_{2}\left(\mathrm{~g} \mathrm{~m}^{-2}\right.$ day $\left.^{-1}\right)$.

\begin{tabular}{|c|c|c|c|c|c|c|c|c|}
\hline & $\mathbf{N}$ & Mean $+(\mathrm{CI})$ & $\mathrm{GM}+(\mathrm{CI})$ & Min & Max & LQ & UQ & St.Dev. \\
\hline \multicolumn{9}{|c|}{ Profile 1} \\
\hline $\mathrm{CO}_{2}$ & 21 & $1.06(0.92-1.30)$ & $0.96(0.85-1.09)$ & 0.30 & 2.60 & 0.80 & 1.20 & 0.52 \\
\hline $\mathrm{O}_{2}$ & 21 & $19.10(18.57-19.62)$ & $19.06(18.50-19-63)$ & 15.10 & 20.30 & 19.00 & 19.60 & 1.15 \\
\hline${ }^{222} \mathrm{Rn}$ & 21 & $9.68(4.57-14.80)$ & 5.31 (3.09-9.11) & 0.49 & 36.90 & 4.03 & 8.16 & 11.24 \\
\hline${ }^{220} \mathrm{Rn}$ & 21 & $9.48(5.95-13.02)$ & $6.53(4.24-10.05)$ & 0.88 & 26.30 & 3.33 & 13.70 & 7.766 \\
\hline$\phi \mathrm{CO}_{2}$ & 21 & $39.54(28.81-50.25)$ & $32.80(24.40-44.08)$ & 10.73 & 88.30 & 21.39 & 53.21 & 23.55 \\
\hline \multicolumn{9}{|c|}{ Profile 2} \\
\hline $\mathrm{CO}_{2}$ & 16 & $0.84(0.71-0.96)$ & $0.79(0.63-0.98)$ & 0.20 & 1.20 & 0.80 & 1.00 & 0.23 \\
\hline $\mathrm{O}_{2}$ & 16 & $19.58(19.38-19.78)$ & 19.58 (19.37-19.78) & 18.60 & 20.10 & 19.45 & 19.80 & 0.37 \\
\hline${ }^{222} \mathrm{Rn}$ & 16 & $3.88(2.56-5.22)$ & $3.17(2.20-4.57)$ & 0.72 & 9.15 & 2.26 & 5.56 & 2.49 \\
\hline${ }^{220} \mathrm{Rn}$ & 16 & $6.72(4.08-9.35)$ & $5.01(3.23-7.79)$ & 1.20 & 14.80 & 2.45 & 10.65 & 4.94 \\
\hline$\phi \mathrm{CO}_{2}$ & 16 & 18.39 (13.44-23.33) & $16.31(12.34-21.54)$ & 4.79 & 42.71 & 12.08 & 25.08 & 9.28 \\
\hline
\end{tabular}


Lewicki et al., [2000] reported comparable anomalous $\mathrm{CO}_{2}$ flux $>18 \mathrm{~g} \mathrm{~m}^{-2}$ day $^{-1}$ along San Andreas Fault.

All studied gases show peaks different in magnitude and distances along the profiles. The spatial distribution of ${ }^{222} \mathrm{Rn}$ and $\mathrm{CO}_{2}$ values along P1 highlights higher values than those measured along P2, but not exclusively, proximal to the coseismic rupture (Fig. 2). Along P1, ${ }^{222} \mathrm{Rn}$ and ${ }^{220} \mathrm{Rn}$ sharp peaks occur on both sides of the hidden fault trace at a distance ranging between $210-240 \mathrm{~m}$ (up to $35 \mathrm{kBq}$ $\mathrm{m}^{-3}$ and $25 \mathrm{kBq} \mathrm{m}^{-3}$, respectively) on the footwall, and a minor peak occurs at a distance of $130 \mathrm{~m}^{2}$ (about $15 \mathrm{kBq} \mathrm{m}^{-3}$ and $10 \mathrm{kBq} \mathrm{m}^{-3}$, respectively) on the hanging wall (Fig. 2a). The lowest ${ }^{222} \mathrm{Rn}$ activity (about $1-2 \mathrm{kBq} \mathrm{m}^{-3}$ ) occur between the two peaks in correspondence of the base of the fault scarp, and beyond the distance of $310 \mathrm{~m}$ where both radon isotopes activity drops to background values (about $6 \mathrm{kBq}$ $\left.\mathrm{m}^{-3}\right)$. $\mathrm{CO}_{2}$ concentrations also follow a similar trend to radon isotopes, being generally higher on both side of the fault than within the fault scarp (1.5-2.5 versus $1.0 \%$ ). Clear major peaks up to $2.5 \%$ occur on the right side of the buried fault at a distance ranging between 210-240 $\mathrm{m}$, and minor peaks (up to $1.5 \%$ ) occur on the left side of the fault at distances of 40 and 130 $\mathrm{m}$, respectively. Along this profile, $\mathrm{CO}_{2}$ background values are below $0.6 \%$; therefore, the minor peaks up to $1.5 \%$, coincident with radon peaks, could also be considered significant. At P2, ${ }^{222} \mathrm{Rn}$ activity increases from 2 to $10 \mathrm{kBq}$ $\mathrm{m}^{-3}$ up to the shallow coseismic rupture (at a distance of about $200 \mathrm{~m}$ ) (Fig.2b); then radon abruptly decreases up to $1-2 \mathrm{kBq} \mathrm{m}^{-3}$ on the right side of the rupture. $\mathrm{CO}_{2}$ concentrations seem to fluctuate around the mean value $(0.8$ $\%$, and shows a sharp decrease at $160 \mathrm{~m}$, about $40 \mathrm{~m}$ from the visible coseismic rupture where the $\mathrm{CO}_{2}$ concentration increases up to
$1.2 \%$. However, the difference between the fault (anomalous) and background populations is not statistically significant along this profile.

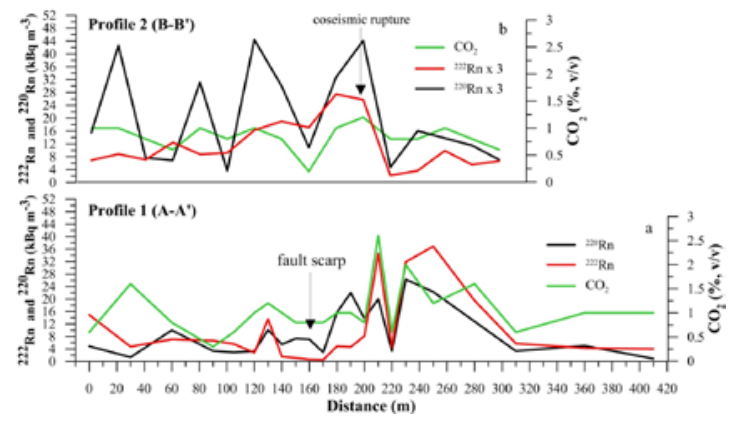

Figure 2. Radon isotopes $\left({ }^{222} \mathrm{Rn}\right.$ and $\left.{ }^{220} \mathrm{Rn}\right)$ and $\mathrm{CO}_{2}$ soil gas profiles carried out across a fault scarp of the $M t$. Vettore fault (profile $\left.1, A-A^{\prime}\right)(a)$, and across a coseismic rupture (profile 2, B-B'). The radon isotope activity along the profile 2 is multiplied by 3 in order to better highlight peaks and for an easy comparison with the higher activities measured along the profile 1.

Figure 3 shows the comparison of $\mathrm{CO}_{2}$ flux measurements $\mathrm{vs}^{\mathrm{CO}_{2}}$ along the two profiles. In both profiles values are significantly higher (about 4 and 2 times, respectively) than the normal $\mathrm{CO} 2$ flux produced by the soil vegetation (maximum $10 \mathrm{~g} \mathrm{~m}^{-2}$ day $^{-1}$ ) of the area [Bahn et al., 2008].

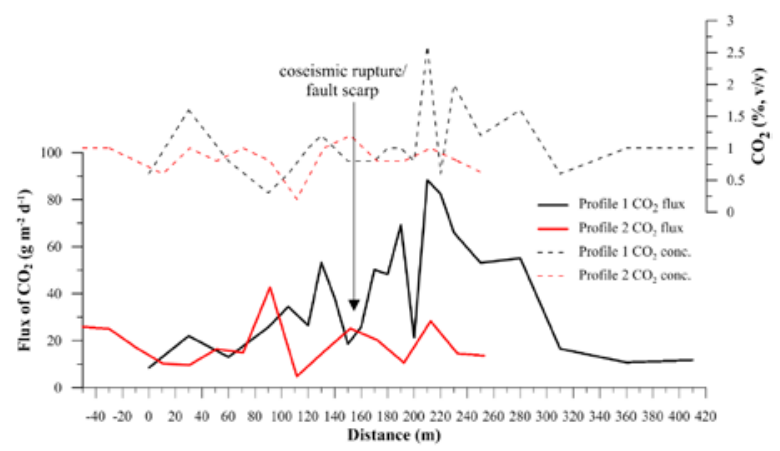

Figure 3. Comparison between the $\mathrm{CO}_{2}$ flux values and the $\mathrm{CO}_{2}$ concentrations measured along the two profiles. 
In particular, P1 shows major peaks more or less coincident (a shifting about $10 \mathrm{~m}$ toward the origin) with those highlighted by soil gas data. Carbon dioxide flux along P2 highlights a good coincidence with the $\mathrm{CO}_{2}$ and ${ }^{220} \mathrm{Rn}$ peaks (Figg. $2 \mathrm{~b}$ and 4 ).

\section{DISCUSSION}

Active faults contribute to gas leaks because they are deep weakened zones composed of highly fractured materials that increase soil permeability at surface. However, the interpretation of a gas anomaly near a fault is a com plex challenge, and involves the evaluation of the type of migration mechanism (i.e., diffusion/advection at different site-specific conditions, including the presence of potential carrier gases), soil composition and thickness, soil permeability, and fracturing.

In the present study, this potential scenario is complicated by the fact that sampling was accomplished in the middle of the seismic sequence of the earthquake of 24 August 2016
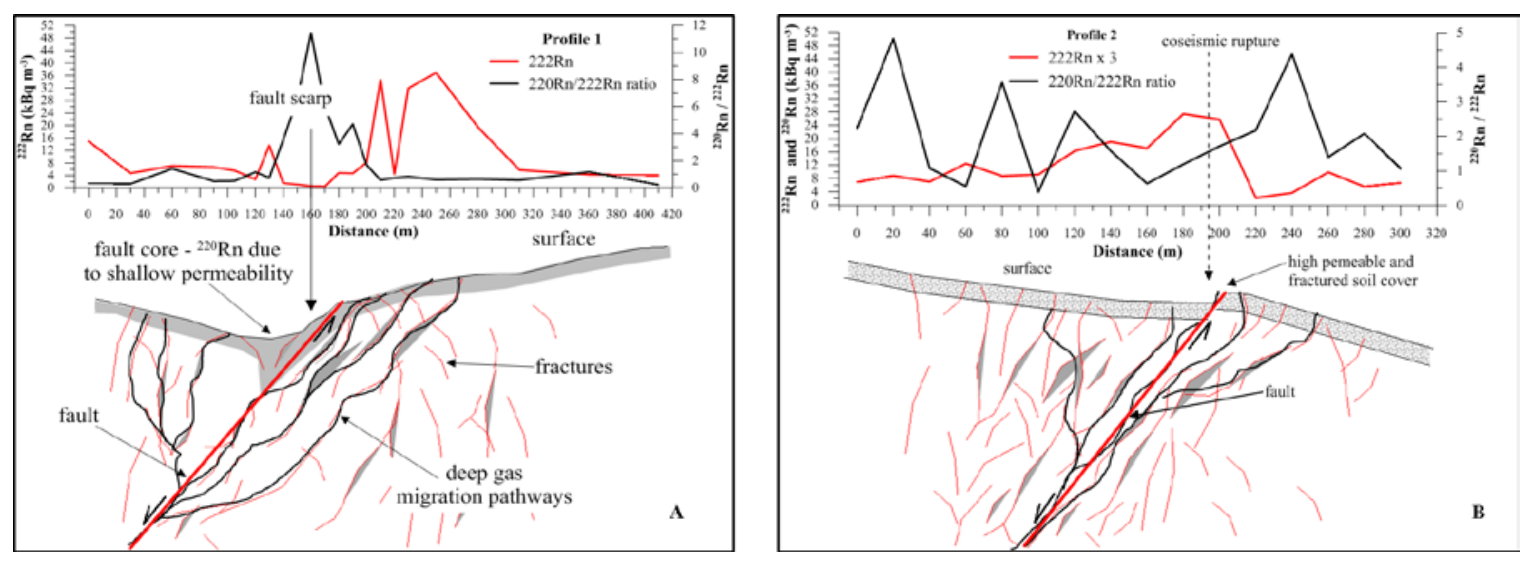

and that, at that time, two events of magnitude 3.9 with epicentres close to about $4 \mathrm{~km}$ from the survey area occurred. In this phase of an earthquake, spike anomalies occur in correspondence of lateral sectors of buried active faults as a result of the opening fractures, as well as diffuse degassing, affected by the shallow conditions (i.e., potential atmospheric dilution), in the exposed fractured areas (Fig. 1a). Soil-gas profiles crossing the buried (P1) and exposed (P2) sectors of the Mt. Vettore fault rupture highlight a non-continuous leakage of tially. In particular, high concentrations were measured along the $\mathrm{P} 1$, with sharp peaks of ${ }^{222} \mathrm{Rn},{ }^{220} \mathrm{Rn}$ and $\mathrm{CO}_{2}$ on both side of the fault, and background values in correspondence the fault core scarp. In contrast, P2 shows lower concentrations of the studied gases, but both ${ }^{222} \mathrm{Rn}$ and ${ }^{220} \mathrm{Rn}$ abruptly drop of their activities on the eastern side of the fault (i.e., footwall). Obtained results can be resumed by the two hypothesised gas leak scenarios (Fig. 4). the studied gases, both in magnitude and spa-

Figure 4. Sketch draws of the two inferred tectonic scenarios along the two profiles: hidden fault with impermeable core, high soil thickness and lateral diffuse fracturing which highlights advective 222 Rnmigration with peaks on both sides of the fault and a peak of ${ }^{220} \mathrm{Rn} / 222 \mathrm{Rn}$ ratio in correspondence of the fault core (A). Exposed coseismic rupture with low soil thickness a diffuse shallow fractures which highlights low concentrations of ${ }^{222} \mathrm{Rn}$ and higher ${ }^{220} \mathrm{Rn}$ peaks due to a diffusive shallow degassing. 
Along P1 coincident peaks of $\mathrm{CO}_{2}$ and radon isotopes on either side of the fault plane, hidden below significant thickness of unconsolidated cover material, can be linked to the extensive fractures proximal to the fault core that significant increase gas channelling and surface leaks. In contrast, the fault core constitutes a less permeable zone where the outgassing rate is decreased by the closure of the fractures caused by the strain changes and formed in the plastic soil cover. However, because in correspondence of hidden faults fractures can remain open at depth, they provided a steady, but reduced gas flux to the surface (Fig. 4a). On the contrary, along P2 lower radon isotopes and $\mathrm{CO}_{2}$ concentrations occur due to the increased permeability caused by the opening of the coseismic fractures during the earthquake, as well as by the low soil thickness that facilitates dilution due to the gas exchange with atmospheric air, therefore masking any deep input. More complex is the interpretation of the $\mathrm{CO}_{2}$ flux that in general is affected by many variables such as, vegetation, soil humidity and temperature, as well as meteorological parameters. The anomalous $\mathrm{CO}_{2}$ flux measured along P1 and P2 suggests the presence of a deeper contribution to the "typical" soil production in this area, as well as a high permeability of the fault zone where both advective (mostly at $\mathrm{P} 1$ ) and diffusive (mostly at P2) contributions occur. In general, high $\mathrm{CO}_{2}$ flux is correlated with high soil gas $\mathrm{CO}_{2}$ concentrations in zones characterised by high permeability dominated by advective transport, but the opposite is not always true due to the many parameters that affected $\mathrm{CO}_{2}$ flux in the shallow environment (Beaubien et al., 2008; West et al., 2015). However, when both $\mathrm{CO}_{2}$ flux and concentration are function of soil production rate, a diffusive transport across soil-air interface can be assumed. Ac- cording to Lewicki et al., [2000], we suppose that in correspondence of high permeable fracture zones (Profile 1) the enhanced near surface diffusion increases advection mechanisms at depth; whereas, in correspondence of the coseismic rupture (Profile 2) a diffusive gas transport provides low $\mathrm{CO}_{2}$ concentrations and high $\mathrm{CO}_{2}$ flux. Considering that samples have been collected during the seismic sequence, the hypothesis that anomalous $\mathrm{CO}_{2}$ flux can be linked to the degassing along the fault damage-zone after the $24^{\text {th }}$ August earthquake cannot be excluded. In support of this hypothesis, it is worth to note that measured $\mathrm{CO}_{2}$ flux values are comparable with those measured during the Emilia 2012 seismic sequence (ranging from 2.3 to 77.3 , mean value $16.8 \mathrm{~g} \mathrm{~m}^{-2}$ day $^{-1}$ ) [Sciarra et al., 2012]. Regarding the origin of the $\mathrm{CO}_{2}$, we refer to Chiodini et al., 2011 (and references therein) in which an input of $\mathrm{CO}_{2}$ derived from metamorphic decarbonation of local carbonates is reported in the regional groundwater aquifers of the Apennines. The interpretation of deep origin radon anomalies along the two profiles may be related to the strain changes during preparation of earthquakes [Holub and Brady, 1981; Ghosh et al., 2009; Zoran et al., 2012; Namvaran and Negarestani, 2012]. Radon is considered an excellent fault tracer, but due to the short half-life of its isotopes ${ }^{220} \mathrm{Rn}$ has a half-life of $55.6 \mathrm{~s}$ and ${ }^{222} \mathrm{Rn}$ has a half-life of 3.82 days), its migration distance is limited. However, where the advective migration occurs, the maximum migration distance is strongly increased by the "carrier effect" of other major gases (i.e., $\mathrm{CO}_{2}$ ); in this context the velocities and the travel distances can reach respectively $0.1-1 \mathrm{~cm} / \mathrm{s}$ and about $1 \mathrm{~m}$ for ${ }^{220} \mathrm{Rn}$ and up to few km for ${ }^{222} \mathrm{Rn}$ [Tanner, 1978; Huxol et al., 2012; Davidson et al., 2016]. Furthermore, the different migration mechanism of each isotope can provide infor- 
mation about the processes that contribute to their concentration near faults. Due to its short migration distances, ${ }^{220} \mathrm{Rn}$ provides indication of radon gas production within soil; in contrast, the ${ }^{222} \mathrm{Rn}$ could migrate both from the soil or from deeper sources, in some cases kilometres below the ground surface. Therefore, the comparison of these two radon isotopes can contribute to distinguish the soil radon emanation from the deep migration with carrier gas. The calculation of ${ }^{220} \mathrm{Rn} /{ }^{222} \mathrm{Rn}$ ratio offers a tool to eliminate the contribution of radon isotopic fraction generated in the shallow soil materials (i.e., ${ }^{220} \mathrm{Rn}$ ). In the profile 1 , the ${ }^{220} \mathrm{Rn} /{ }^{222} \mathrm{Rn}$ ratio shows a clear peak in the area of the fault scarp, and a rapid drop on both side of the fault. This behaviour is in contrast with the ${ }^{222} \mathrm{Rn}$ along the profile and supports the hypothesis that in the fault core a radon production occurs due to the high porosity of the shallow cover material that masks the radon gas migration from deep opened fractures (Fig. 4a). On the contrary, the ${ }^{220} \mathrm{Rn} / 222 \mathrm{Rn}$ ratio along the P2 figures out the same behaviour of ${ }^{220} \mathrm{Rn}$, thus demonstrating that the shallow production of this isotope is originated in the soil, and diffuses at surface due to high fracturing that pervades the exposed coseismic rupture (Fig. $4 b)$.

\section{CONCLUSION}

Soil gas and $\mathrm{CO}_{2}$ flux anomalous values have been recorded in correspondence of buried and exposed sectors of the active Mt. Vettore fault system that generated the strong earthquake $\left(\mathrm{M}_{\mathrm{L}}=6.0\right)$ on 24 August 2016. Elevated ${ }^{222} \mathrm{Rn},{ }^{220} \mathrm{Rn}$ and $\mathrm{CO}_{2}$ gas concentrations, as well as $\mathrm{CO}_{2}$ flux values were measured along $\mathrm{P} 1$ on both side of the buried fault due to gas advection within the fault-related fracture zone. Along P2 the lower soil gas concentrations can be partially attributed to local pro- duction and to the increased permeability of this area caused by scarce soil thickness and the presence of high fracturing of the exposed fault rupture. Although $\mathrm{CO}_{2}$ flux measurements could be affected by site-specific conditions, the high measured values, as well as the coincidence with the peaks of the other soil gases, suggest a degassing process along the buried and exposed fault sectors probably linked to the occurring seismic sequence. Results confirms that soil gases in general, but especially ${ }^{222} \mathrm{Rn}$, constitute excellent tracers of buried faults, whereas in correspondence of the coseismic rupture degassing processes are demonstrated only by flux measurements probably related to the seismic activity that enhanced gas leakage underground.

The obtained results encourage the renewal of the research about the use of radon and other gases as earthquake precursors. At this regard, two multi-parametric geochemical monitoring stations (gasPRO) will be deployed proximal to the Mt. Vettore fault and to the Gorzano fault (few kilometer south). This last active fault, activated during the L'Aquila seismic sequence in 2009 [Bigi et al., 2012] crosses a high exposure zone due to the presence of the dam of Rio Fucino, Campotosto lake (central Italy). The continuous monitoring of geochemical parameters in the areas of high seismicity, and along active fault zones, could help to better describe the leakage variation through these structure. In fact, usually measurements are performed after the main earthquakes events and few information are available for gas/fluid activity and circulation during the pre-seismic period of time. This period instead is characterized by physical variation theoretically well known, but not so 
well described in terms of observed variation of field parameters.

\section{REFERENCES}

AMA_LOC Working Group (2016). Amatrice 2016 main events re-location (v1.0 - 20160902 12.00). Istituto Nazionale di Geofisica e Vulcanologia. DOI 10.5281/zenodo.61371.

Annunziatellis, A., Beaubien, S.E., Bigi, S., Ciotoli, G., Coltella, M., Lombardi, S. (2008). Gas migration along fault systems and through the vadose zone in the Latera caldera (central Italy): Implications for $\mathrm{CO}_{2}$ geological storage. Int. J. Greenh. Gas Control, 2:353-372.

Bahn, M., Rodeghiero, M., Anderson-Dunn, M., et al. (2008). Soil respiration in European grasslands in relation to climate and assimilate supply. Ecosystems, 11(8): 1352-1367.

Baubron, J.C., Rigo, A., Toutain, J.P. (2002). Soil gas profiles as a tool to characterize active tectonic areas: The Jaut Pass example (Pyrenees, France). Earth Planet. Sci. Lett., 196:6981.

Beaubien, S.E., Ruggiero, L., Annunziatellis, A., Bigi, S., Ciotoli, G., Deiana, P., Graziani, S., Lombardi, S., Tartarello M.C. (2015). The importance of baseline surveys of near-surface gas geochemistry for CCS monitoring, as shown from onshore case studies in Northern and Southern Europe. Oil \& Gas Science and Technology - Rev. IFP Energies nouvelles, Vol. 70 (4): 615-633, doi: 10.2516/ogst/2014009.

Beaubien, S.E., Ciotoli, G., Cooms, P., Dictor, M.C., Krüger, M., Lombardi, S., Pearce, J.M., West, J.M. (2008). The impact of a naturally occurring $\mathrm{CO}_{2}$ gas vent on the shallow ecosystem and soil chemistry of a Mediterranean pasture
(Latera, Italy). Intern. J. Greenhouse Gas Control, 2(3): 373-387.

Bigi, S., Milli, S., Corrado, S., Casero, P., Aldega, L., Botti, F., Moscatelli, M., Stanzione, O., Falcini, F., Marini, M., and Cannata, D. (2009). Stratigraphy, structural setting and thermal history of the Messinian Laga Basin in the context of Apennine foreland basin system. J. Med. Earth Sciences, 1: 61-84.

Bigi, S., Casero, P., Ciotoli, G., (2011). Seismic interpretation of the Laga basin; constraints on the structural setting and kinematics of the Central Apennines. J. Geol. Soc. London, 168: 179-190.

Bigi, S., Beaubien, S.E., Ciotoli, G., D'Ambrogi, C., Doglioni, C., Ferrante, V., Lombardi, S., Milli, S., Orlando, L., Ruggiero, L., Tartarello, M.C., Sacco, P. (2014). Mantle-derived $\mathrm{CO}_{2}$ migration along active faults within an extensional basin margin (Fiumicino, Rome, Italy). Tectonophys., 637:137-149.

Boni, C., Bono., P., Capelli, G. (1987). Hydrogeological scheme of Central Italy. Ed. Centro di studio per la geologia dell'Italia centrale, Consiglio Nazionale delle Ricerche, Roma.

Boni, C., Petitta, M. (2007). Studio idrogeologico per l'identificazione e la caratterizzazione degli acquiferi che alimentano le sorgenti dei corsi d'acqua perenni dei Monti Sibillini, esteso all'intera area del Parco Nazionale. Rapporto definitivo. Contratto di studio e ricerca. Autorità di Bacino del Fiume Tevere - Parco Nazionale dei Monti Sibillini - Dipartimento Scienze della Terra Università di Roma "La Sapienza".

Calamita, F., and Pizzi, A. (1993). Tettonica quaternaria nella dorsale appenninica umbromarchigiana e bacini intrappenninici associati. Studi Geol. Camerti, 1: 17-26. 
Calamita, F., Pizzi, A., and Roscioni, M. (1993). I "fasci" di faglie recenti ed attive di M. Vettore-M. Bove e di M. Castello-M. Cardosa (Appennino umbro-marchigiano). Studi Geol. Camerti, 1: 81-95.

Centamore, E., Adamoli, L., Berti, D., Bigi, G., Bigi, S., Casnedi, R., Cantalamessa, G., Fumanti, F., Morelli, C., Micarelli, A., Ridolfi, M., and Salvucci, R. (1992). Carta geologica dei bacini della Laga e del Cellino e dei rilievi carbonatici circostanti. In: Studi Geologici Camerti, Vol. Spec. Università degli Studi, Dipartimento di Scienze della Terra. SELCA, Firenze.

Chiodini, G., Caliro, S., Cardellini, C., Frondini, F., Inguaggiato, S., Matteucci, F. (2011). Geochemical evidence for and characterization of $\mathrm{CO}_{2}$ rich gas sources in the epicentral area of the Abruzzo 2009 earthquakes. EPSL, 304: 389398.

Ciotoli, G., Lombardi, S., Annunziatellis, A. (2007). Geostatistical analysis of soil gas data in a high seismic intermontane basin: Fucino Plain, central Italy. J. Geophys. Res. 112, B05407.

http://dx.doi.org/10.1029/2005JB004044.

Ciotoli, G., Bigi, S., Cavinato, G.P. (2015). Radon distribution as shallow evidence of buried fault geometry in the Fucino plain (Central Ita1y). Conference: 6th International INQUA Meeting on Paleoseismology, Active Tectonics and Archaeoseismology, 19-24 April 2015, Pescina, Fucino Basin, Italy, At Pescina (AQ, Italy), Volume: Miscellanea INGV, vol 27, ISSN 20396651.

Ciotoli, G., Etiope, G., Marra, F., Florindo, F., Giraudi, C., Ruggiero, L. (2016). Tiber delta $\mathrm{CO}_{2}-\mathrm{CH}_{4}$ degassing: A possible hybrid, tectonically active Sediment-Hosted Geothermal
System near Rome. J. Geophys. Res. Solid Earth, 121:48-69, doi:10.1002/2015JB012557.

Collettini, C., Cardellini, C., Chiodini, G., De Paola, N., Holdsworth, R.E., Smith, S.A.F. (2008). Fault weakening due to $\mathrm{CO}_{2}$ degassing in the Northern Apennines: short- and longterm processes. In: Wiberley, C.A.J., Kurz, W., Imber, J., Holddsworth, R.E., Collettini, C. (Eds.), The Internal Structure of Fault Zones: Implications for Mechanical and Fluid-Flow Properties. Geological Society, London, pp. 175-194.

Davidson, J.R.J., Fairley, J., Nicol, A., Gravley, D., Ring, U. (2016). The origin of radon anomalies along faults in an active rift and geothermal area. Geosphere, DOI: 10.1130/GES01321.1

Fu, C.C., Yang, T.F., Du, J., Walia, V., Chen, Y.G. (2008). Variations of helium and radon concentrations in soil gases from an active fault zone in Southern Taiwan. Radiat. Meas. 43: S348-S352.

Ghosh, D., Deb, A., Sengupta, R. (2009). Anomalous radon emission as precursor of earthquake. J. App. Geophy.s 69: 67-81.

Hashemi, S., Negarestani, A., Namvaran, M., Nasab, S.M.M. (2013). An analytical algorithm for designing radon monitoring network to predict the location and magnitude of, earthquakes. J. Radioanal. Nucl. Chem. 295: 22492262.

Hinkle, M. (1994). Environmental conditions affecting concentrations of $\mathrm{He}, \mathrm{CO}_{2}, \mathrm{O}_{2}$ and $\mathrm{N}_{2}$ in soil gases. Appl. Geochem., 9: 53-63.

Holub, R.F., Brady, B.T. (1981). The effect of stress on radon emanation from rock. J. Geophys. Res., 86(B3):1776-1784.

Huxol, S., Brennwald, M., Hoehn, E., Kipfer, R. (2012). On the fate of ${ }^{220} \mathrm{Rn}$ in soil material in 
dependence of water content: Implications from field and laboratory experiments. Chem. Geol., 298-299:116-122.

King, C.Y. (1985). Impulsive radon emanation on a creeping segment of the San Andreas fault, California. Pure Appl. Geophys., 122: 340-352.

King, C.Y., King, B.S., Evans, W.C., Zhang, W. (1996). Spatial radon anomalies on active faults in California. Appl. Geochem., 11:497-510. doi:10.1016/0883-2927(96)00003-0.

Koike, K., Yoshinaga, T., and Asaue, H. (2009). Radon concentrations in soil gas, considering radioactive equilibrium conditions with application to estimating fault zone geometry. Environ. Geol., 56:1533-1549.

Lewicki, J.L., Brantley, S.L. (2000). CO2 degassing along the San Andreas fault, Parkfield, California. Geoph. Res. Lett., 27:5-8.

Metzger, C., Jansson1, P.E., Lohila, A., Aurela, M., Eickenscheidt, T., Belelli-Marchesini, L., Dinsmore, K.J., Drewer, J., van Huissteden, J., Drösler, M. (2008). $\mathrm{CO}_{2}$ fluxes and ecosystem dynamics at five European treeless peatlands merging data and process oriented modeling. Biogeosciences, 12:125-146, doi:10.5194/bg-12125-2015.

Milli, S., Moscatelli, M., Stanzione, O., Falcini, F. (2007). Sedimentology and physical stratigraphy of the Messinian turbidite deposits of the Laga Basin (central Apennines, Italy). Boll. Soc. Geol. It., 126: 255-281.

Mollo, S., Tuccimei, P., Heap, M.J., Vinciguerra, S., Soligo, M., Castelluccio, M., Scarlato, P., Dingwell, D.B. (2011). Increase in radon emission due to rock failure: an experimental study. Geophys. Res. Lett., 38, L14304.
Namvaran, M., Negarestani, A. (2012). Measuring the radon concentration and investigating the mechanism of decline prior an earthquake (Jooshan, SE of Iran). J. Radioanal. Nucl. Chem., 298: 1-8.

Nanni, T., Petitta, M. (2012). Studio del bacino idrogeologico carbonatico (Monti Sibillini) del fiume Aso finalizzato alla caratterizzazione delle condizioni di alimentazione e di circolazione idrica, alla

valutazione del bilancio idrogeologico e analisi della sorgente di Foce. Seconda Fase. CIIP Spa - Ascoli Piceno.

Pierantoni, P., Deiana, G., and Galdenzi, S. (2013). Stratigraphic and structural features of the Sibillini Mountains (Umbria-Marche Apennines, Italy). Italian Journal of Geosciences, 132(3): 497- 520.

Perez, N.M., Hernandez, P.A., Padron, E., Melian, G., Marrero, R. (2007). Precursory Subsurface ${ }^{222} \mathrm{Rn}$ and ${ }^{220} \mathrm{Rn}$ Degassing Signatures of the 2004 Seismic Crisis at Tenerife, Canary Islands. Pure Appl. Geophys. 164:2431- 2448.

Petraki, E., Nikolopoulos, D., Panagiotaras, D., Cantzos, D., Yannakopoulos, P. (2015). Radon222: A Potential Short-Term Earthquake Precursor. J. Earth Sci. Clim. Change., 6: 282. doi:10.4172/2157-7617.1000282.

Reddy, D.V., Sukhija, B.S., Nagabhushanam, P., Kumar, D. (2004). A clear case of radon anomaly associated with a microearthquake event in a stable continental region. Geophys. Res. Lett. 31: L10609.

Rice, J.R. (1992). Fault stress states, pore pressure redistributions, and the weakness of the San Andreas fault. In: Evans, B., Wong, T.F. (Eds.), Fault Mechanics and Transport Proper- 
ties of Rock. Academic Press Ltd., San Diego, pp. 476-503

Sciarra, A., Cantucci, B., Buttinelli, M., Galli, G., Nazzari, M., Pizzino, L., Quattrocchi F. (2012). Soil-gas survey of liquefaction and collapsed caves during the Emilia seismic sequence. Ann. Goephys., 55(4):803-809. doi: 10.4401/ag-6122

Sciarra, A., Fascetti, A., Moretti, A., Cantucci, B., Pizzino, L., Lombardi, S., Guerra, I. (2014). Geochemical and radiometric profiles through an active fault in the Sila Massif (Calabria, Italy). J. Geoch. Explor., 148:128-137. http://dx.doi.org/10.1016/j.gexplo.2014.08.015.

Sibson, R.H. (2000). Fluid involvement in normal faulting. J. Geodyn. 29: 449-469.Sinclair, A.J. (1991). A fundamental approach to threshold estimation in exploration geochemistry: Probability plots revisited. J.Geochem. Explor., 41:1-22.

Tanner, A.B. (1964). Radon migration in the ground: A review. Nat. Rad. Env., I:161-268.

Tanner, A.B. (1978). Radon migration in the ground: A supplementary review. Nat. Rad. Env., III:5-56.

Tavani, S., Storti, F., Bausà, J., and Munoz, J.A. (2012). Late thrusting extensional collapse at the mountain front of the Northern Apennines (Italy). Tectonics, 31 (4). doi: 10.1029/2011TC003059.
Wakita, H., Nakamura, Y., Notsu, K., Noguchi, M., Asada, T. (1980). Radon anomaly: a possible precursor to the 1978 Izu-Oshima-kinkai earthquake. Science, 207: 882-883.

Walia, V., Yang, T.F., Hong, W. L., Lin, S. J., $\mathrm{Fu}$, C. C., Wen, K. L., Chen, C. H. (2009). Geochemical variation of soil-gas composition for fault trace and earthquake precursory studies along the Hsincheng fault in NW Taiwan. Appl. Radiat. Isotopes 67:1855-1863, doi: 10.1016/j.apradiso.2009.07.004.

Xiaocheng Zhou, X., Jianguo Du, J., Chen, Z., Cheng, J., Tang, Y., Yang, L., Xie, C., Cui, Y., Lei, L., Yi, L., Yang, P., Li, Y. (2010). Geochemistry of soil gas in the seismic fault zone produced by the Wenchuan Ms 8.0 earthquake, southwestern China. Geochem. Trans., 11: 5, doi: 10.1186/1467-4866-11-5.

Zoran, M., Savastru, R., Savastru, D., Chitaru, C., Baschir, L. (2012). Monitoring of radon anomalies in South-Eastern part of Romania for earthquake surveillance. J. Radioanal. Nucl. Chem., 293:769-781.

Z.S. Žunic, Z.S., Kozak, K., Ciotoli, G., Mazur, J., Ramola, R.C., Kochowska, E., Ujic, P., Celikovic, I., Janik, M., Yarmoshenko, I.V., Demajo, A., Birovljev, A., Bochicchio, F., Kryeziu, D., Olko, P. (2007). A campaign of discrete radon concentration measurements in soil of Niška Banja town, Serbia. Radiation Measurements 42: $1696-1702$. 